\title{
Nutritional and Phytochemical Compositions of the Leaves of Mucuna Poggei
}

\author{
A. O. Oko (Correspondence author) \\ Department of Biotechnology, Ebonyi State University \\ P.M.B. 053 Abakaliki, Ebonyi State, Nigeria \\ Tel: 234-803-261-3614Ｅ-mail: austineok@yahoo.co.uk \\ J. C. Ekigbo \\ Department of Biotechnology, Ebonyi State University \\ P.M.B. 053 Abakaliki, Ebonyi State, Nigeria \\ J. N. Idenyi \\ Department of Biotechnology, Ebonyi State University \\ P.M.B. 053 Abakaliki, Ebonyi State, Nigeria \\ L. U. Ehihia \\ Department of Biochemistry, Ebonyi State University \\ P.M.B. 053 Abakaliki, Ebonyi State
}

Received: June 1, 2012 Accepted: June 15, 2012

doi:10.5296/jbls.v3i1.2218 URL: http://dx.doi.org/10.5296/jbls.v3i1.2218

\begin{abstract}
The chemical nutrient composition and the phytochemical content of the leaves of Mucuna poggei, an underutilized leafy vegetable were analyzed using standard methods. The result of the proximate compositions analysis showed that the leaves contained moisture $(8.25 \%)$, crude fibre $(30.55 \%)$, crude fat $(9.45 \%)$, ash $(7.78 \%)$, crude protein $(32.38 \%)$ and carbohydrate $(11.55 \%)$. Results of the mineral analysis showed that it contains the following essential minerals: Sodium $(68.10 \mathrm{mg} / 100 \mathrm{~g})$, potassium $(43.21 \mathrm{mg} / 100 \mathrm{~g})$, calcium
\end{abstract}


$(71.71 \mathrm{mg} / 100 \mathrm{~g})$, iron $(10.56 \mathrm{mg} / 100 \mathrm{~g})$, manganese $(0.65 \mathrm{mg} / 100 \mathrm{~g})$, copper $(0.47 \mathrm{mg} / 100 \mathrm{~g})$, magnesium $(56.05 \mathrm{mg} / 100 \mathrm{~g})$, zinc $(0.25 \mathrm{mg} / 100 \mathrm{~g})$, phosphorus $(5.72 \mathrm{mg} / 100 \mathrm{~g})$, lead $(0.01 \mathrm{mg} / 100 \mathrm{~g})$, cobalt (nil) and cadmium (nil). The high protein and fibre contents as well as other proximate components are a desirable attribute. The concentration of iron shows that Mucuna poggei leaves could help in boosting of blood level in anaemic conditions. The phytochemical screening of the leaves revealed the presence of alkaloids, tannins, carbohydrates, terpenoids, balsams and triterpenoids. These results rank the leaves of Mucuna poggei among the best in terms of essential nutrients composition when compared with those of other edible leaves in literature.

Keywords: Mucuna poggei, Leaf composition, Mineral content, Nutrition.

\section{Introduction}

It has been observed that there is an increased awareness on the importance of wild or semi-wild plants owing to their high vitamins, minerals, essential fatty acids and fibre contents (Tukan et al., 1998). Although conventional food plants have the capabilities of providing most of the nutrients needed for energy, body building, maintenance and regulation of body processes, the need to explore some seemingly unappealing sources of nutrient have become imperative owing to the serious threat to growth, development and survival posed by increasing population, food insecurity and economic crises in most developing nations like Nigeria (Hassan et al., 2007). Most of these are utilized to provide not only nutrients but also traditional treatment for various ailments.

Mucuna poggei is one of such plants with physical characteristics that are repelling to both human and animals from getting closer. It is of the family: Fabaceae, Subfamily: Faboideae, Tribe: Phaseoleae, Subtribe: Erythrininae, Genus: Mucuna, Species: poggei and Variety: Mucuna poggei var. pesa (GRIN, 2006). It is widely distributed in the Democratic Republic of Congo, Tanzania, Uganda, Malawi, Mozambique, Zambia and Zimbabwe (Hyde, 2012). It is known as "horse eye bean" and other local names in respect to different tribes and ethnic groups exist. It is called "agbara" by Igbos; "matara" by Hausas; "igbekpe" in Benin, and "werepe" by Yorubas (Adewale and Mozie, 2010). Mucuna poggei (Figure 1)is a trifoliate trimming annual climber known as the farmer's enemy. Flowers are creamy or yellowish. The leaves are silky-pubescent beneath. Fruits are covered by itchy hairs that break loose on slight touching when fully dry in savannah woody and deciduous forest and secondary jungle (Bisby et al., 2007). In fact, a critical description of Mucuna poggei presents it as a vigorous, large liane plant with stems attaining 12-30 m in length. Leaflets are rhomboid, ovate or obovate, with laterals very asymmetrical, $10-19 \mathrm{~cm}$ long, 6-15.5 cm wide, apiculate or rounded at the apex, rounded to subcordate at the base, sparsely ad pressed pubescent above, densely adpressed silvery grey beneath or in some variants woolly or glabrescent but for hairs on the nerves; stipules triangular. Inflorescences are pendulous, usually with numerous flowers; grayish or ferruginous tomentose. There are several flowers per node which are standard greenish-white or yellowish, ovate to elliptic; wings and keel greenish-cream, sometimes with tinge of purple along the edges. Pods are 2-5-seeded, 14-20 cm long, 3.5-4 cm wide, $1.8 \mathrm{~cm}$ thick, densely covered with deciduous orange-brown or orange-red bristly very irritant hairs. 
Seeds of Mucuna are purple or pale brown with dense dark brown mottling that are irregularly elliptic-oblong and much compressed (Ibrahim, 1989)

Mucuna plants have been reported to possess useful phytochemicals of high medicinal value of human and veterinary importance and also serve as raw material in Ayurvedic and folk medicines (Sridhar and Bhat, 2007). The seeds of Mucuna poggei have very rich amino acid profile when compared with other species, containing the highest percentage of lysine among others (Tuleun et al., 2008). However, information on the nutritional content of the leaves of Mucuna poggei is still very scanty.

In order to boost their blood levels, most rural dwellers in some parts of Nigeria, especially the Igbo speaking people have resorted to oral administration of the crude aqueous extract of Mucuna poggei as the cheapest source of multivitamins. This study therefore focuses on the phytochemical screening, mineral analysis and the proximate analysis of Mucuna poggei leaves with a view to assessing its nutritional potentials in relation to its ethnomedicinal uses.

\section{Materials and Methods}

\section{Sample collection}

Fresh plants of Mucuna poggei were collected from Ukehe in Igbo Etiti L.G.A of Enugu State Nigeria. Identification of the species and variety were done at the Botany Department of Ebonyi State University Abakaliki, Nigeria. The leaves were separated from the stalks, washed and room dried for 3 weeks, blended into fine powder using blending machine and stored in a covered plastic container for further use. All reagents were of analytical grade unless otherwise stated. Distilled/deionized water was used in the preparation of solutions.

\section{Sample analysis}

The proximate analyses were carried out in triplicates and the results obtained were the average values. The estimation of the various nutrient parameters in Mucuna poggei leave was carried out using the methods of AOAC (1990).

Mineral analysis were carried out after acid digestion of $2 \mathrm{~g}$ of the grounded leave sample with $10 \mathrm{ml}$ of a mixture of nitric acid and perchloric acid $(2: 1 \mathrm{v} / \mathrm{v})$ until a clear solution was obtained. The digest was allowed to cool and then transferred into a $100 \mathrm{ml}$ standard flask and made up to mark with de-ionized water. The mineral elements were analyzed with atomic absorption spectrophotometer (GBC Avanta Ver 2.02 Model, Australia) equipped with air-acetylene flame. The phosphorus content was determined colorimetrically using spectro 21D (PEC medicals, USA) spectrophotometer while sodium and potassium were determined using a flame photometer (Gallenkamp flame analyser, UK).

Phytochemical screening procedures carried out were by the method of Odebiyi and Sowofora after $10 \mathrm{~g}$ of Mucuna poggei leaves were soaked in $100 \mathrm{ml}$ ethanol for $24 \mathrm{hrs}$ and then filtered.

\section{Results and Discussion}

Table 1 presents the result for the proximate analysis of Mucuna poggei leaves. It shows that 
it contains $11.55 \%$ of carbohydrate, $32.38 \%$ crude protein, $7.78 \%$ ash, $30.55 \%$ crude fibre, $9.45 \%$ fat and $8.25 \%$ moisture. Protein had the highest percentage value while ash had the least.

The crude fibre content of $M$. poggei leaves (30.55\%) was higher than 3.65\% reported for seeds of 12 Mucuna accessions in Nigeria (Ezegu et al., 2003); 8.61\% reported for Amaranthus hybridus (Akubugwo et al., 2007) and 22.36\% reported by Hassan and Ngaski (2007). This quality of the Mucuna poggei leaves is highly desirable because adequate intake of dietary fibre can lower serum cholesterol level, risk of coronary heart disease, hypertension, constipation, diabetes, colon and breast cancer (Rao and Newmark, 1998; Ishida et al., 2000).

The crude protein content $(32.38 \%)$ was quite higher than the reported values of some Nigerian leafy vegetables (Hassan and Umar, 2006; Hassan and Ngaski, 2007; Nnamani et al., 2009; Onwordi et al., 2009; Puangpronpitag et al., 2010). This indicates that Mucuna poggei leaf is a good source of protein of dietary protein supplement to meet the recommended daily requirement for humans (FND, 2002). The importance of protein to animals and human health cannot be over emphasized, therefore Mucuna poggei leaves could be used both as feed and food protein supplements.

The leaves contained $9.45 \%$ crude lipid, which is lower than the values reported for water spinach leaves and Senna obtusfolia, but higher when than the values seen in spinach leaves, chaya leaves and Amaranthus hybridus leaves (Nwaogu et al., 2000). Crude lipids are the principal sources of energy but should be consumed with caution so as to avoid obesity and other related diseases. A diet providing 1-2\% of its caloric energy as fat is sufficient in human beings as excessive consumption has been implicated in certain cardiovascular disorders such as atherosclerosis, cancer and aging (Antia et al., 2006).

The ash content of $7.73 \%$ indicates that the leaves are rich in mineral elements. This value is higher than that reported for sweet potato leaves and Tribulus terrestris leaves, but lower than some leafy vegetables commonly consumed in Nigeria such as Talinum triangulare, Occimum graticimum and Hibiscus esculentum (Asibey-Berko and Tanyie, 1999; Nwaogu et al., 2000; Akindahunsi and Salawu, 2005).

The moisture content was lower than those reported for Acalypha hispida, Acalypha racemosa and Acalypha maginata (Iniaghe et al, 2009). The low moisture content of the leaves would hinder the growth of micro organisms and shelve life could be higher (Adeyeye and Ayejuyo, 1994).The carbohydrate content of the leaves (11.55\%) is considerably low compared to some other leafy vegetables like Tribulus terrestris "Tsaida" and Corchorus tridens (Asibey-Berko and Tayie, 1999).

The result of mineral analysis (table 2) showed that calcium had the highest concentration $(71.71 \mathrm{mg} / 100 \mathrm{~g})$. Considering the importance of Calcium for the growth and maintenance of bones, teeth and muscles, this value could be said to be low since it can only contribute about 5.9\% to the Recommended Daily Allowance (RDA) values of calcium for an adult man with $300 \mathrm{kcal} /$ day whose recommended energy intake is 1200mg (NRC, 1989; Dosunmu, 1997; 
Turan et al., 2003). This implies that Mucuna poggei can slightly contribute to the amount of dietary calcium. The phosphorus content was also low $(5.72 \mathrm{mg} / 100 \mathrm{~g})$. Calcium and phosphorus are the minerals present in the largest quantity in the structure of the body and bones. The concept of $\mathrm{Ca} / \mathrm{P}$ ratio as introduced by Shills and Young (1988) takes into cognizance that diets rich in animal proteins and phosphorus, promotes the loss of calcium in urine, resulting in a decrease of calcium levels in bones. Niemen et al., (1992) considered a food source good if the $\mathrm{Ca} / \mathrm{P}$ is above 1 and poor if the ratio is less than 0.5 . Mucuna poggei leaves with $12.54 \mathrm{Ca} / \mathrm{P}$ are therefore a good source of minerals needed in bone formation.

The potassium content of Mucuna poggei $(43.21 \mathrm{mg} / 100 \mathrm{~g})$ is higher than the values found in Indigofera astragelina leave, but lower than in Cassia siemea leaves (Gafar et al., 2011; Ngaski, 2006). However, this value is very and can only contribute very little to the body requirement of the dietary potassium. The leaves of Mucuna poggei can only contribute about $2.1 \%$ of the Recommended Daily Allowance (RDA) of potassium which is $2000 \mathrm{mg}$ for adults (NRC, 1989). The Sodium content of Mucuna poggei leaves $68.10 \mathrm{mg} / 100 \mathrm{~g}$ was higher than that of Senna obtusfoliat leaves (Lintas, 1992). Mucuna poggei leaves can contribute about $13.6 \%$ to RDA since the RDA value for sodium for adult is $500 \mathrm{mg}$ (NRC, 1989). The importance of $\mathrm{Na} / \mathrm{K}$ ratio in the body in controlling high blood pressure cannot be over emphasized (Yusuf et al., 2007). Mucuna poggei leaves with $1.58 \mathrm{Na} / \mathrm{K}$ is good and adequate; therefore, use of the leaves as vegetable in diets could be useful in lowering blood pressure. Magnesium is an important mineral element in connection with its role in circulatory diseases such as ischemic heart disease and calcium metabolism in bone (Ishida et al., 2000; Hassan and Umar, 2006). The magnesium content of the leaves is $56.05 \mathrm{mg} / 100 \mathrm{~g}$ which is higher than the value reported for Amaranthus hybridus leaves (Nwaogu et al., 2000) but lower than that of Cassia siamea leaves (Ngaski, 2006). Mucuna poggei leaves can contribute about $16.01 \%$ to RDA since the RDA for magnesium in adult is 350mg (NRC, 1989). This means the leaf can serve as a source of magnesium.

Copper is important in diet since it is a very powerful pro-oxidant and catalyzes the oxidation of unsaturated fats and oil as well as ascorbic acid (John, 1999). The copper content of Mucuna poggei was $0.47 \mathrm{mg} / 100 \mathrm{~g}$ which is far much higher than values in Indigofera astragelina leave (Gafar et al., 2011), but lower than the value in T. terrestris leaves (Hassan et al., 2005). Mucuna poggei leaves could also serve as a fair source of copper in both animal and human diets since the RDA value for copper is $1.5-3 \mathrm{mg}$ for a male adult and 15.67-31.33\% are contributed to the RDA by Mucuna pogge(NRC, 1989).

The iron content of Mucuna poggei was $10.58 \mathrm{mg} / 100 \mathrm{~g}$ which is high when compared with the values found in T. terrestis and in some cultivated vegetables such as spinach, lettuce and cabbage, but lower than $70.00 \mathrm{mg} / 100 \mathrm{~g}$ in cassia siamea (Turan et al., 2003; Ngaski, 2006). The importance of iron as a trace element in the body can be seen in its role in hemoglobin formation, normal functioning of the central nervous system and oxidation of carbohydrates, protein and fats (Adeyeye and Okokiti, 1999). This value for iron shows that Mucuna poggei leaves could help in boosting the blood level in anaemic conditions (NRC, 1989). Rural dwellers who use the leaves to treat such conditions have claimed huge successes and this percentage iron content of Mucuna poggei tends to support their claim. 
The zinc content of Mucuna poggei is $0.25 \mathrm{mg} / 100 \mathrm{~g}$ which is greater than that found $I$. astragelina leaves than that found in Cassia siamea leaves (Gafar et al., 2011; Ngaski, 2006). As an essential element in the nutrition of man zinc functions as an integral part of numerous enzymes or as a stabilizer of the molecular structure of sub-cellular constituents and membrane and as well participates in the synthesis and degradation of carbohydrates, lipids, protein and nucleic acids and has shown to play an essential role in polynucleotide transcription and translation and thus in the process of genetic expression (WHO, 1996). Mucuna poggei leaves can contribute about 1.70-1.67\% of the RDA value of zinc which for male adult is $12-15 \mathrm{mg}$ (NRC, 1989). This implies that the leaves are a poor source of zinc.

Manganese is another micro element essential for human nutrition, acting as inactivator for many enzymes (MacDonald et al., 1995). The manganese content in Mucuna poggei iwas about $0.65 \mathrm{mg} / 100 \mathrm{~g}$ which is slightly higher than the values found in I. astragalina leaves, but lower than $0.98-38.0 \mathrm{mg} / 100 \mathrm{~g}$ reported in some locally green leafy vegetables and $11.6 \mathrm{mg} / 100 \mathrm{~g}$ in Balassam apple (Momordica balsamina L.) leaves (Gafar et al., 2011; Hassan and Umar, 2006). The RDA value for manganese is $2-5 \mathrm{mg} / 100 \mathrm{~g}$ for a male adult and Mucuna poggei leaves can contribute about $32.5-13.0 \%$ of manganese to the RDA and could be said to be a fairly good source of manganese (NRC, 1989).

Cobalt and Cadmium were absent, but the concentration of lead $(0.01 \mathrm{mg} / 100 \mathrm{~g})$ in Mucuna poggei cannot lead to any health hazard in consumers since it is lower than the maximum permissible limit of $3 \mathrm{mg} / 100 \mathrm{~g}$ lead for vegetables and thus falls within safe limits for consumption(FAO/WHO, 2001).

The results of phytochemical screening (table 3) indicated the presence of balsams, tannins, triterpenoids, saponins, alkaloids, terpenoids and carbohydrates. The presence of these secondary metabolites has contributed to its medicinal value as well as physiological activity (Safowara, 1996). Various studies have shown that saponins although non toxic can generate adverse physiological responses in animals that consume them. They exhibit cytoxic effects and growth inhibitions against a variety of cells, making them have anti-inflammatory and anticancer properties. They also show tumour inhibiting activities on animals (Akindahunsi and Salawu, 2005). Steroidal compounds are of importance in pharmacy because of their relationship with such compounds as sex hormones (Okwu, 2001). The presence of some the antinutrients found in the Mucuna poggei leaves can be reduced by various processing techniques (Siegler, 1998).

\section{Conclusion}

From the study, one can deduce that Mucuna poggei leaves may serve as constituents of human diet supplying the body with minerals, proteins and crude fibre. The presence of secondary metabolites that are biologically important contributes to its medicinal value and thus can be a potential source of useful drugs. 


\section{MInstitute ${ }_{\text {Mnk }}^{\text {Macrothink }}$}

Journal of Biology and Life Science ISSN 2157-6076 2012, Vol. 3, No. 1

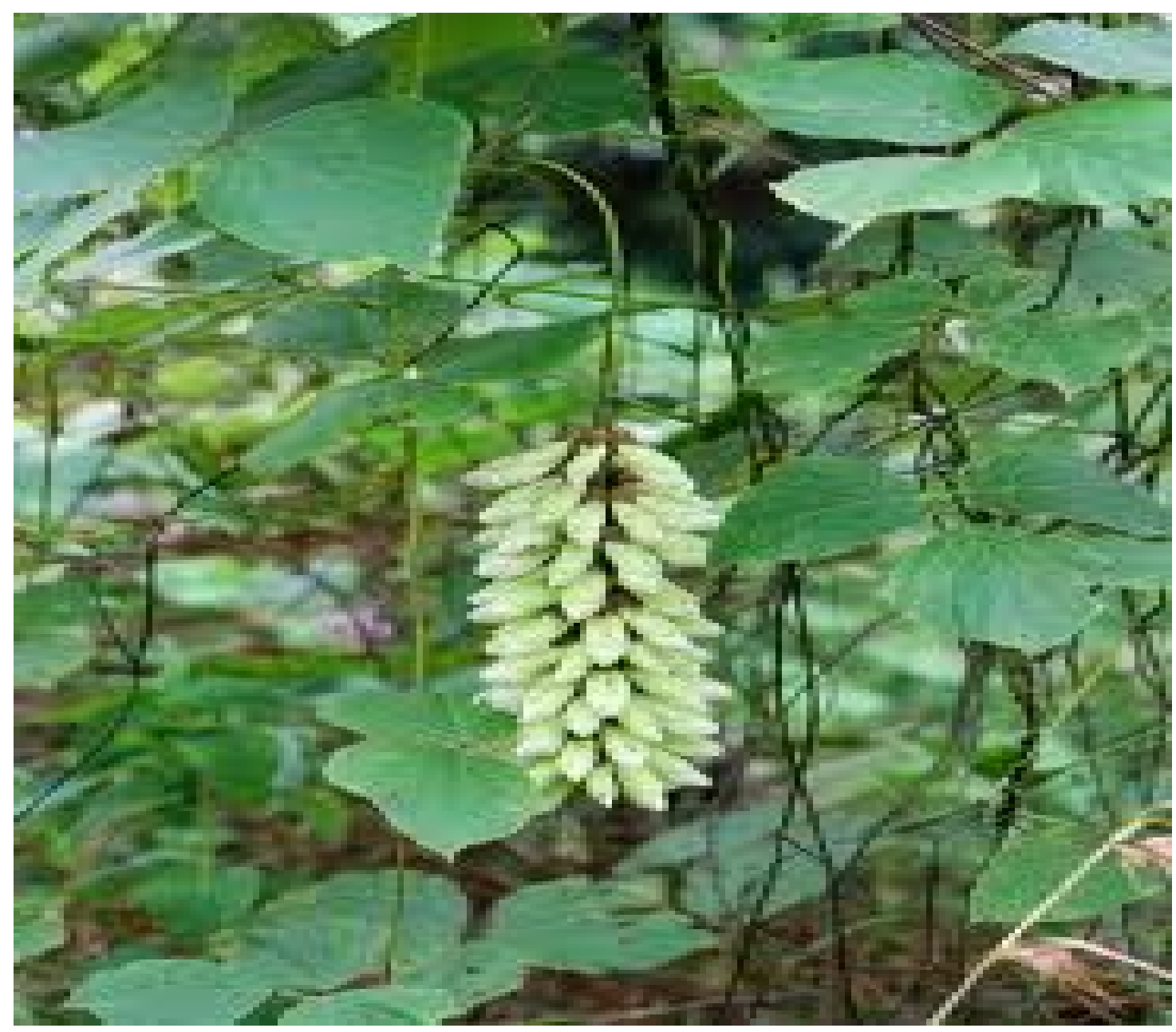

Figure 1. Mucuna poggei plant

Table 1. Chemical composition of Mucuna poggei leaves

\begin{tabular}{|l|l|}
\hline Component & Value (\%) \\
\hline Moisture & $8.25 \%$ \\
\hline Crude fibre & $30.55 \%$ \\
\hline Crude fat & $9.45 \%$ \\
\hline Ash & $7.78 \%$ \\
\hline Crude Protein & $32.38 \%$ \\
\hline Carbohydrates & $11.55 \%$ \\
\hline
\end{tabular}

Table 2. Mineral composition of Mucuna poggei leaves

\begin{tabular}{|l|l|}
\hline Minerals & Concentration $(\mathbf{m g} / \mathbf{1 0 0 g})$ \\
\hline Sodium & 68.10 \\
\hline Potassium & 43.21 \\
\hline Calcium & 71.71 \\
\hline Iron & 10.58 \\
\hline Manganese & 0.65 \\
\hline Copper & 0.47 \\
\hline Magnesium & 56.05 \\
\hline Zinc & 0.24 \\
\hline
\end{tabular}




\begin{tabular}{|l|l|}
\hline Cobalt & Nil \\
\hline Lead & 0.01 \\
\hline Cadmium & Nil \\
\hline Phosphorus & 5.72 \\
\hline $\mathrm{Na} / \mathrm{K}$ & 1.58 \\
\hline $\mathrm{Ca} / \mathrm{P}$ & 12.54 \\
\hline
\end{tabular}

Table 3. Phytochemical screening of Mucuna poggei leaves

\begin{tabular}{|l|l|}
\hline Phytochemicals & Result \\
\hline Balsams & + \\
\hline Tannins & + \\
\hline Steroids & - \\
\hline Triterpenoids & + \\
\hline Glycosides & - \\
\hline Antraquinones & - \\
\hline Saponins & + \\
\hline Phenols & - \\
\hline Alkaloids & + \\
\hline Cardenolides & - \\
\hline Terpenoids & + \\
\hline Carbohydrates & + \\
\hline Flavonoids & - \\
\hline Cardiac Glycosides & - \\
\hline Phlobatanannins & - \\
\hline
\end{tabular}

$+=$ Positive $\quad-=$ Negative

\section{References}

Adeyeye, E. I. \& Okokiti, M. K. (1999). Proximate composition and some nutritional valuable Minerals of two varieties of Capsicum annum (Bell and Cherry peppers). Discovery Innovation, 11, 75-81.

Adeyeye, E. I. \& Ayejuyo, O. O. (1994). Chemical composition of Cola accuminata and Grarcina kola seed grown in Nigeria. International Journal of Food Science and Nutrition, 45, 223-230.

Akindahunsi, A. A. \& Salawu, S. O. (2005). hytochemical screening and nutrient-antinutrient composition of selected tropical green leafy vegetables. African Journal of Biotechnology, 4, 497- 501.

Akubugwo, I. E., Obasi, N. A., Chinyere , G. C. \& Ugbogu, A. E. (2007). Nutritional and chemical value of Amaranthus hybridus leaves from Afikpo, Nigeria. African Journal of Biotechnology, 6, 2833- 2839.

Antia, B. S., Akpan, E. J., Okon, P. A. \& Umoren, I. U. (2006). Proximate Composition and Phytochemical Constituents of Leaves of some Acalypha species. Pakistani Journal of 
Nutrition, 5, 166-168

AOAC. (1990). Official Methods of Analysis. 15th Edition, Association of Official AnalyticalChemists, Washington DC.

Asibey-Berko E. \& Tayei, F. A. K. (1999). Proximate Analysis of some Under Utilized Ghanaian vegetables. Ghana Journal of Science, 39, 91-92.

Bisby, F. A., Roskiv, Y. R., Ruggiero, M. A., Ovrell, T. M., Paglinawa, L. E., Brewer, P. W.... Badly, N. \& Van, H. (2007). Species 2000 and IT IS catalogue of life. 2007 Annual Checklist Species 2000 Reading, U.K.

Dosunmu, M. I. (1997). Chemical Composition of the Fruit of Tetraptera and the Physico-Chemical Properties of its oil. Global Journal of Pure and Applied Science, 3, 61-67.

Ezegu, I. E., Maziya-Dixon, B. \& Tarawali, G. (2003). Seed Characteristics and Nutrient and Antinutrient Composition of 12 Mucuna accessions from Nigeria. Tropical and subtropical Agroecocyst, 1, 129-140.

FAO/WHO. (2001). Codex Alimentarius Commission Food additives and contaminants. Joint FAO/WHO Food Standards Programme, ALINORM 01/12A:1-289.

FND. (2002). Dietary Reference Intake for Energy, Carbohydrate, Fibre, Fat, Fatty Acids, Cholesterol, Protein and Amino Acid (micronutrients). FND, National Academy of Science USA.

Gafar M. K., Itodo, A. U., Atiku, F. A., Hassan, A. M. \& Peni, I. J. (2011). Proximate and mineral composition of the leaves of hairy indigo (Indigofera astragalina). Pakistan Journal of Nutrition, 10(2), 168-175.

Germplasm Resources Information Network (GRIN). (2006). Mucuna poggei US Department of Agriculture, Agricultural Research Service. http://www.ars-grin.gov/npgs/aboutgrin.html

Hassan, L.G. \& Ngaski, M. M. A. (2007). Nutritional Evaluation of Cassia siamen leaves. Journal of Chem. Soc. Nig., 32, 137-143.

Hassan, L. G., Umar, K. J. \& Tijjani, A. A. (2007). Preliminary Investigation of the Feed Quality of Monechma cilition Seeds. Chem. Class Journal, 4, 83.

Hassan, L. G. \& Umar, K. J. (2006). Nutritional Value of Balsam Apple (Moordica balsamina) Leaves. Pakistan Journal of Nutrition, 5, 522-529.

Hassan, L. G., Umar, K. J. Dangogo, S. M. \& Ladan, M. J. (2005). Protein and Amino Acids Composition of African Locust Bean (Parkia bigblobosa L.). Journal of Tropical and Subtropical Agroesystems.

Hyde, M. A., Wursten, B. T. \& Ballings, P. (2012). Flora of Zimbabwe: Species information: Mucuna poggei var. pesa. http://www.zimbabweflora.co.zw/speciesdata/species.php 
Ibrahim, K. M. (1989). An illustrated manual of Kenya legumes. Kitale, Kenya, FAO-UNDP, 656.

Iniaghe O. M., Malomo S. O. \& Adebayo J. O. (2009). Proximate Composition and Phytochemical Constituents of Leaves of some Acalypha species. Pakistan Journal of Nutrition, 8(3), 256-258.

Ishida, H., Suzuno, H., Sugiyama, N., Innami, S., Todokoro, T. \& Maekawa, A. (2000). Nutritional Evaluation of Chemical Component of Leaves and Stems of Sweet Potatoes (Ipomoea batatas poir). Food Chemistry, 68, 359-367.

John, M. M. (1999). Principles of Food Chemistry, 3rd edition, 209-223. Lintas, C. (1992). Nutritional Aspects of Fruits and Vegetables Consumption. Options medierraeenes, 19, 7987.

National Research Council (NRC). (1989). Recommended Dietary allowances. National Academy Press, Washington, DC.

Ngaski, M. M. (2006). Phytochemical Screening and Proximate Analysis of Cassia siemea Leaves. M.Sc Dissertation (unpolished) Submitted to Postgraduate School, Usmanu Danfodiyo University Sokoto.

Nnamani, C. V., Oselebe, H. O. \& Agbatutu, A. (2009). Assessment of Nutritional Values of Three Underutilized Indigenous Leafy Vegetable of Ebonyi State, Nigeria. African Journal Biotechnology, 8, 2321- 2324.

Nwaogu, L. A., Ujuwundu, C. O. \& Mgbemena, A. I. (2000). Studies on the nutritional and phytochemical Composition of Amaratus hybridus leaves. Bis-Res, 4, 28-31.

Okwu, D. E. (2001). Evaluation of the chemical composition of indigenous spices and flavouring Agents. Global Journal of Pure and Applied Science, 7, 455-459.

Onword, C. T., Ogungbade, A. M. \&. Wusu, A. D. (2009). The Proximate and Mineral Composition of Three Leafy Vegetables Commonly Consumed in Lagos, Nigeria. African Journal of Pure and Applied Chemistry, 3, 102-107.

Rao, C. V. \& Newmark, H. L. (1998). Chemo-preventive effect of squalene on colon cancer. Carcinogenesis, 19, 287-290.

Safowara, E. A. (1996). Medicinal Plants and Traditional Medicine in Africa. Spectrum Books Ltd, Ibadan, 55-71.

Shills, M. E. G and Young, V. R. (1988). Nutrition, Brown publishers, Dubugye USA. 276-282.

Sridhar, K. R \& Bhat, R. (2007). Agrobotanical, Nutritional and Bioactive Potential of Unconventional Legume-Mucuna. Livestock Res. Rural Dev. 19, 126-130.

Tukan, S. K., Takruri, H. R. \& Al-Eisaw, D. M. (1998). The use of wild edible plants in the Jordanian diet. International Journal of Food Science and Nutrition, 49, 225-235. 


\section{Macrothink}

Journal of Biology and Life Science ISSN 2157-6076 2012, Vol. 3, No. 1

Tuleun, C. D., Carew, S. N. \& Patrick, J. A. (2008). Fruit characteristics and chemical composition of some varieties of velvet beans (Mucuna spp) found in Benue State of Nigeria. Livestock Research for Rural Development, 20, 10.

Turan, M., Kordis, S. Zeyin, H. Dursan, A. \& Sezen, Y. (2003). Macro and micro minerals content in Some Wild Edible Leaves consumed in Eastern Anatolia. Tailors and Francis, 129-130.

Yusuf, A. A., Mofio, B. M. \& Ahmed, A. B. (2007). Proximate and Mineral Composition of Tamarindus indica linn1753 seeds. Science World Journal, 2, 1-4.

\section{Copyright Disclaimer}

Copyright reserved by the author(s).

This article is an open-access article distributed under the terms and conditions of the Creative Commons Attribution license (http://creativecommons.org/licenses/by/3.0/). 